\title{
Pengaruh industri kecil terhadap pertumbuhan ekonomi di Provinsi Jambi
}

\author{
Febriani Sitanggang*; Purwaka Hari Prihanto; Etik Umiyati
}

Prodi Ekonomi Pembangunan, Fak. Ekonomi dan Bisnis, Universitas Jambi

*E-mail korespodensi: sitanggangfebriani@gmail.com

\begin{abstract}
This study aims to determine the effect of the number of business units, investment, and labor on economic growth in Jambi Province in 2001-2017. This type of research is descriptive quantitative. The use of secondary data from the publication of the Central Statistics Agency of Jambi Province in the form of time series data, namely Economic Growth, number of small industrial business units, small industrial investment, small industrial workforce. The results showed that, from the results of the t-test, it can be concluded that for each small industrial business unit variable, the number of small industrial business units and small industrial workers has a significant effect on economic growth. The results of the coefficient of determination test $\left(R^{2}\right)$ show that the ability of the independent variables (small industrial business units, small industrial investment and small industrial workers) in explaining the dependent variable (economic growth) is 98.69 percent. In comparison, the variable others explain the remaining 1.31 percent outside the model.
\end{abstract}

Keywords: Economic growth, Business units, Labor, Investment

\begin{abstract}
Abstrak
Penelitian ini bertujuan untuk mengetahui pengaruh jumlah unit usaha, investasi, dan tenaga kerja terhadap pertumbuhan ekonomi di Provinsi Jambi tahun 2001-2017. Jenis penelitian berupa deskriptif kuantitatif. Penggunaan data sekunder dari publikasi Badan Pusat Statistik Provinsi Jambi berupa data time series yaitu Pertumbuhan Ekonomi, jumlah unit usaha industri kecil, Investasi industri kecil, Tenaga Kerja industri kecil. Hasil penelitian didapatkan bahwa, dari hasil uji-t dapat disimpulkan untuk masing-masing variabel unit usaha indsutri kecil, jumlah unit usaha industri kecil dan tenaga kerja industri kecil berpengaruh signifikan terhadap pertumbuhan ekonomi. Hasil uji koefisien determinasi $\left(\mathrm{R}^{2}\right)$ menunjukkan bahwa kemampuan variabel independen (unit usaha industri kecil, investasi industri kecil dan tenaga kerja industri kecil) dalam menjelaskan variabel dependen (pertumbuhan ekonomi) adalah sebesar 98,69 persen sedangkan sisanya 1,31 persen dijelaskan oleh variabel lain di luar model.
\end{abstract}

Kata kunci: Pertumbuhan ekonomi, Unit usaha, Tenaga kerja, Investasi

\section{PENDAHULUAN}

Pembangunan merupakan proses natural mewujudkan cita-cita ber Negara, yaitu mewujudkan masyarakat makmur sejahtera secara adil dan merata. Pembangunan juga 
merupakan suatu proses yang berkelanjutan untuk menuju pada kehidupan ekonomi rakyat dengan segala aspek kehidupan ekonomi, politik, harga diri, kepercayaan diri, kreativitas, solidaritas antar sesama, dan sebuah kemerdekaan yang berfungsi social (Rahardja, 2008)

Tujuan pembangunan ekonomi setiap Negara adalah tercapainya pembangunan ekonomi yang adil dan merata. Pembangunan ekonomi adalah sebuah usaha untuk meningkatkan taraf hidup suatu bangsa yang diukur melalui tinggi rendahnya pendapatan per kapita. Pembangunan ekonomi merupakan suatu proses multidimensi yang melibatkan perubahan-perubahan besar dalam struktur sosial, sikap masyarakat, dan kelembagaan nasional, seperti halnya percepatan pertumbuhan ekonomi, pengurangan ketidakmerataan dan pemberantasan kemiskinan absolut. (Sukirno,2000)

Indonesia merupakan Negara yang sedang berkembang. Pembangunan ekonomi yang dilaksanakan oleh Negara berkembang bertujuan memeratakan pembangunan ekonomi dan hasilnya kepada seluruh masyarakat, meningkatkan laju pertumbuhan ekonomi, meningkatkan kesempatan kerja, pemerataan pendapatan, mengurangi perbedaan kemampuan antar daerah, struktur perekonomian yang seimbang.

Salah satu ukuran pembangunan dan pertumbuhan ekonomi suatu Negara dapat dilihat dari pendapatan nasional nya. Ukuran pendapatan nasional yang sering digunakan adalah Produk Domestik Bruto. Produk Domestik Bruto (PDB) diartikan sebagai total nilai atau harga pasar (market prices) dari seluruh barang dan jasa akhir (final goods and services) yang dihasilkan oleh suatu perekonomian selama kurun waktu tertentu (biasanya 1 tahun) Jadi PDB merupakan indikator penting untuk mengetahui kondisi ekonomi di suatu Negara. Apabila PDB-nya menunjukkan adanya peningkatan, maka dapat dikatakan perekonomian Negara tersebut menjadi lebih baik dari tahun sebelumnya.(Todaro, 2011)

Salah satu bentuk pemberdayaan yang ada di Indonesia adalah pemberdayaan Usaha Kecil Menengah (UKM) yang secara langsung maupun tidak langsung berpengaruh terhadap pertumbuhan ekonomi daerah yang kemudian juga berpengaruh terhadap perekonomian secara nasional. Ketika terjadi krisis ekonomi 1998, hanya sektor UKM yang bertahan dari kolapsnya ekonomi, sementara sektor usaha yang lebih besar (UB) justru tumbang oleh krisis. Krisis ini telah mengakibatkan kedudukan posisi pelaku sektor ekonomi berubah. Usaha besar satu persatu mengalami bangkrut karena bahan baku impor meningkat secara drastis, biaya cicilan utang meningkat sebagai akibat dari nilai tukar rupiah terhadap dollar yang menurun dan berfluktuasi. Sektor perbankan yang ikut terpuruk turut memperparah sektor industri dari sisi permodalan. Banyak perusahaan yang tidak mampu lagi meneruskan usaha karena tingkat bunga yang tinggi. Berbeda dengan UKM yang sebagian besar tetap bertahan, bahkan cenderung bertambah.(Widodo, 2006)

Dalam pembangunan ekonomi di Indonesia UKM selalu digambarkan sebagai sektor yang mempunyai peranan penting, karena sebagian besar jumlah penduduknya berpendidikan rendah dan hidup dalam kegiatan usaha kecil baik di sektor tradisional maupun modern. Serta mampu menyerap banyak tenaga kerja. Peranan usaha kecil tersebut menjadi bagian yang diutamakan dalam setiap perencanaan tahapan pembangunan yang dikelola oleh dua Departemen yaitu Departemen Perindustrian dan Perdagangan, serta Departemen Koperasi dan UKM.

Peran penting UKM secara umum dapat kita lihat dari perkembangan yang signifikan dan peran UKM sebagai penyumbang PDB terbesar di Indonesia. Pada tahun 2007 hingga tahun 2012 menunjukkan peningkatan jumlah PDB UKM dari Rp. 2,107,868.10 Milyar menjadi Rp. 4,869,568.10 Milyar atau rata-rata mengalami perkembangan sebesar 
18.33\%/tahun. Kemudian pada Usaha Besar (UB) sumbangsih terhadap perkembangan PDB lebih sedikit dibandingkan UKM, dengan Persentase rata-rata perkembangan sebesar $15.75 \%$ per tahun. Dari data statistik yang yang diperoleh dari BPS, pada tahun 2012 UKM menyerap 97,16\% dari total tenaga kerja Industri di Indonesia atau sebesar 107.66 juta, sisanya atau sebesar $2.84 \%$ tenaga kerja diserap oleh sektor Usaha Besar ( Badan Pusat Statistik 2017)

Hal tersebut menunjukkan bagaimana peran UKM sangat dominan dalam pertumbuhan ekonomi Indonesia. Sehingga pemberdayaan UKM merupakan sesuatu yang sangat penting dalam upaya meningkatkan pertumbuhan perekonomian di Indonesia. Sumbangsih UKM terhadap PDB menjadikan indikator pentingnya UKM dalam peningkatan pertumbuhan perekonomian di Indonesia, Produk Domestik Bruto (PDB) merupakan indikator pertumbuhan perekonomian, dimana pertumbuhan ekonomi adalah proses kenaikan output perkapita dalam jangka yang panjang . Output perkapita sekarang ini kita kenal sebagai Produk Domestik Bruto (PDB). PDB sendiri sangat berkaitan erat dengan jumlah penduduk sehingga PDB sangat dipengaruhi jumlah penduduk dan jangka waktu yang panjang, jadi pertumbuhan ekonomi merupakan suatu proses.

Pengembangan usaha kecil menengah (UKM) sesuai arah kebijakan pembangunan bidang ekonomi sesuai dengan RPJM Nasional tahun 2010-2014 yang merupakan Pedoman bagi seluruh komponen bangsa baik itu pemerintah, masyarakat dan dunia usaha, dalam mewujudkan cita-cita dan tujuan nasional secara sinergis, koordinatif, dan saling melengkapi.

Provinsi Jambi menjadi salah satu wilayah yang menarik dan berpotensi untuk pengembangan dunia usaha. Pengembangan UKM dan sektor pariwisata akan mempengaruhi secara signifikan peningkatan perekonomian baik individu maupun keseluruhan Provinsi Jambi. Sebab, Peranan UKM sangat penting dalam menumbuhkan dan mengembangkan potensi ekonomi rakyat serta dalam mewujudkan kehidupan demokrasi ekonomi yang bercirikan demokratis, kebersamaan, kekeluargaan dan keterbukaan. Dalam kehidupan ekonomi rakyat, UKM memiliki ruang gerak dan kesempatan usaha yang luas, terutama yang menyangkut kepentingan kehidupan ekonomi rakyat. Untuk mengetahui gambaran pertumbuhan PDRB Provinsi Jambi, unit usaha industri kecil Provinsi Jambi, nilai investasi Industri kecil dan Investasi industry kecil di Provinsi Jambi dalam waktu lima tahun terakhir dapat dilihat pada tabel dibawah ini.

Di Provinsi Jambi pertumbuhan PDRB menunjukan perkembangan yg cenderung meningkat . Dari hasil perhitungan PDRB, telah diketahui bahwa total nilai PDRB Provinsi Jambi pada tahun 2011 meningkat sebesar 8.51 persen, berikutnya tahun 2012 dan 2013 agak melambat masing-masing mengalami pertumbuhan sebesar 7,44 persen dan 6,12 persen, kemudian tahun 2014 mengalami penurunan lagi dengan perolehan pertumbuhan sebesar 5.03 persen, namun pada tahun 2015 dan 2016 kembali meningkat masing-masing mengalami pertumbuhan sebesar 6.55 dan 5.35 persen, pada tahun 2017 juga mengalami peningkatan sebesar 5.73 persen. ( Badan Pusat Statistik Provinsi Jambi 2017 )

Perkembangan unit usaha industri kecil di Provinsi Jambi selama periode 2011-2017 menunjukkan perkembangan yang cenderung meningkat, peningkatan ini sebagai salah satu bukti bahwa usaha kecil ini memiliki peranan yang cukup besar bagi pembangunan dan pertumbuhan ekonomi daerah. Pada tahun 2011 jumlah unit usaha di Provinsi Jambi sebesar 78.459, kemudian mengalami peningkatan kembali sebesar 79.119 unit usaha kecil di tahun 2012. Sementara pada tahun 2013 jumlah unit usaha kecil di Provinsi Jambi adalah 
sebesar 81.552 atau mengalami pertumbuhan sebesar 3,08 persen dari tahun sebelumnya. Pada tahun 2014 jumlah umit usaha kecil di Provinsi Jambi mengalami peningkatan sebesar 81.959 kemudian ditahun 2015 unit usaha kecil di Provinsi Jambi terus mengalami peningkatan sebesar 81.979 atau mengalami pertumbuhan sebesar 0.02 persen, dan pada Tahun 2016 dan 2017 jumlah unit usaha kecil di Provinsi Jambi semakin meningkat yaitu sebesar 98.105 dan 99.910 pada tahun 2017 atau mengalami peningkatan sebesar 19,67 persen dan 1.83 persen dari tahun sebelumnya.( Badan Pusat Statistik Provinsi Jambi 2017)

Perkembangan nilai investasi di Provinsi Jambi selama periode 2011-2017 menunjukkan perkembangan yang cenderung meningkat, peningkatan ini sebagai salah satu bukti bahwa usaha kecil ini memiliki peranan yang cukup besar bagi pembangunan dan pertumbuhan ekonomi Wilayah, Kota dan Daerah. Pada tahun 2011 jumlah nilai investasi di Provinsi Jambi sebesar Rp.14.387.175 kemudian mengalami peningkatan sebesar Rp.14.430.379. pada tahun 2012. Sementara pada tahun 2013 jumlah nilai investasi di Provinsi Jambi adalah sebesar Rp.15.210.000 atau mengalami pertumbuhan sebesar 4.99 persen dari tahun sebelumnya. Pada tahun 2014 jumlah nilai investasi di Provinsi Jambi mengalami peningkatan sebesar Rp.15.970.000 atau mengalami pertumbuhan sebesar 4.99 persen, kemudian ditahun 2015 jumlah nilai investasi di Provinsi Jambi terus mengalami penurunan sebesar Rp.14.227.868 atau mengalami penurunan pertumbuhan sebesar -10.9 persen. sedangkan pada tahun 2016 dan 2017 jumlah nilai investasi di Provinsi Jambi kembali meningkat sebesar Rp.15.717.941 dan Rp16.753.329 pada tahun 2017 atau mengalami peningkatan pertumbuhan sebesar sebesar 10.47 persen dan 6.58 persen pada tahun 2017 (BPS Provinsi Jambi 2017)

Adapun pertumbuhan tenaga kerja di Provinsi Jambi selama periode 2011-2017 menunjukkan perkembangan yang juga cenderung meningkat dimana pada tahun 2011 jumlah tenaga kerja industri kecil di Provinsi Jambi adalah sebesar 110.108 orang, kemudian mengalami peningkatan kembali sebesar 119.932 orang di tahun 2012. Sementara pada tahun 2013 jumlah tenaga kerja industri kecil di Provinsi Jambi adalah sebesar 153.761 orang atau mengalami pertumbuhan sebesar 28.2 persen dari tahun sebelumnya, pada tahun 2014 jumlah tenaga kerja industri kecil di Provinsi Jambi terus mengalami peningkatan yaitu sebesar 154.147 orang atau mengalami pertumbuhan sebesar 0.25 persen di tahun 2015 tenaga kerja semakin meningkat yaitu meningkat sebesar 168.288 orang atau mengalami pertumbuhan sebesar 9.17 persen Sedangkan pada tahun 2016 jumlah tenaga kerja adalah sebesar 173.442 orang atau mengalami peningkatan sebesar 3.06 persen dan pada Tahun 2017 tetap mengalami peningkatan jumlah tenaga kerja yaitu sebanyak 181.843 orang atau mengalami pertumbuhan sebesar 4.8 persen ( BPS Provinsi Jambi 2017).

Berdasarkan latar belakang tersebut, penelitian ini bertujuan untuk menganalisis: (1)Bagaimana perkembangan unit usaha industri kecil ,tenaga kerja industri kecil dan investasi industri kecil di Provinsi Jambi periode 2001-2017 (2) Bagaimana pengaruh, unit usaha industri kecil , tenaga kerja industri kecil dan investasi industri kecil terhadap pertumbuhan ekonomi di Provinsi Jambi periode 2001-2017.

\section{METODE}

Dalam penelitian ini data yang digunakan adalah data sekunder, dalam rentang waktu tahun 2001-2017 meliputi data PDRB Provinsi Jambi, data unit usaha industri kecil 
Provinsi Jambi, data tenaga kerja industri kecil Provinsi Jambi dan data investasi industri kecil Provinsi Jambi. Sumber data yang digunakan dalam penelitian ini berasal dari: Badan Pusat Statistik (BPS) Provinsi Jambi

Analisis deskriptif yaitu analisis yang dihasilkan dengan cara merumuskan dan mengumpulkan data, mengklarifikasikan serta menginterpretasikannya sehingga memberi suatu penjelasan dari gambaran yang ada. Untuk menjawab masalah yang pertama laju pertumbuhan ekonomi digunakan rumus untuk menghitung tingkat pertumbuhan ekonomi (Junaidi, 2015)

$$
\mathbf{G}=\frac{P D R B_{t}-P D R B_{t-1}}{P D R B_{t-1}} \times 100
$$

\section{Dimana :}

$\mathrm{G} \quad=$ laju pertumbuhan ekonomi

PDRBt = pertumbuhan ekonomi tahun sekarang

PDRBt $_{-1}=$ pertumbuhan ekonomi tahun sebelumnya

Untuk menjawab permasalahan kedua pengaruh unit usaha indistri kecil, tenaga industri kecil, investasi industry kecil terhadap pertumbuhan ekonomi di Provinsi Jambi menggunakan rumus sebagai berikut:

$$
\mathrm{Y}=\boldsymbol{\beta}_{\mathbf{0}}+\boldsymbol{\beta} 1 \mathrm{X} 1+\boldsymbol{\beta} 2 \mathrm{X} 2+\beta 3 \mathrm{X3}+\mathrm{e}
$$

Dimana :

$$
\begin{array}{ll}
\log \mathrm{Y} & =\text { PDRB }(\% \\
\text { 乃o } & =\text { Konstanta } \\
\mathrm{X} 1 & =\text { Unit usaha industri kecil (Unit) } \\
\mathrm{X} 2 & =\text { Tenaga kerja industri kecil (orang) } \\
\mathrm{X} 3 & =\text { Investasi industri kecil (Rp) } \\
\mathrm{e} & =\text { Faktor Lain }
\end{array}
$$

\section{Uji statistik}

\section{Uji simultan (uji F)}

Uji F dilakukan untuk mengetahui pengaruh variabel bebas (X) secara keseluruhan terhadap variabel terikat (Y). Kesimpulan uji $\mathrm{F}$ dapat diperoleh dengan membandingkan antara nilai $\mathrm{F}$ probabilita dengan nilai $\mathrm{F}$ pada tingkat keyakinan tertentu.Pengujian ini dilakukan dengan rumus sebagai berikut :

$$
\begin{aligned}
& \mathrm{F}_{\text {hitung }}=\frac{\frac{\mathrm{R} 2}{\mathrm{~K}}-1}{(1-\mathrm{R} 2)(\mathrm{n}-\mathrm{K})} \\
& \text { Dimana } \\
& \mathrm{R} 2 \quad=\text { Koefisien determinan } \\
& \mathrm{k} \quad=\text { Jumlah variabel bebas } \\
& \mathrm{n} \quad=\text { Jumlah sampel }
\end{aligned}
$$


Bila F-hitung > F-tabel, maka $\mathrm{H}_{0}$ dittolak, berarti secara bersama-sama variabel bebas $(\mathrm{X})$ berpengaruh secara nyata dan signifikan terhadap variabel terikat (y). bila Fhitung < F-tabel, maka $\mathrm{H}_{0}$ diterima, berarti secara Bersama-sama variabel bebas $(\mathrm{X})$ tidak berpengaruh secara nyata terhadap variabel terikat (Y).

\section{Uji parsial (uji t)}

Uji t dilakukan untuk mengetahui pengaruh variabel bebas $(\mathrm{X})$ terhadap variabel terikat (Y), kesimpulan hasil uji t dilakukan dengan membandingkan nilai t hitung dengan $\mathrm{t}$ tabel. Pengujian ini di lakukan dengan menggunakan rumus sebagai berikut:

$$
t_{\text {hitung }}=\frac{\beta \mathrm{i}}{\operatorname{Se}(\beta \mathrm{i})}
$$

Dimana :

$\beta \mathrm{i} \quad=$ Elastiitas variabel ke (i)

$\mathrm{Se} \beta \mathrm{i}=$ Standar Error

Bila $t_{\text {hitung }}>t_{\text {tabel }}$ berdasarkan tingkat keyakinan tertentu, maka $\mathrm{H}_{0}$ ditolak, berarti tiap-tiap variabel berpengaruh secara nyata terhadap variabel terikat. Bila $t_{h i t u n g}<t_{\text {tabel }}$, berdasarkan tingkat keyakinan tertentu, maka $\mathrm{H}_{0}$ diterimsa, berarti tiap-tiap variabel bebas tidak berpengaruh secara nyata terhadap variabel terikat.

\section{Koefisien determinasi $\left(\mathbf{R}^{2}\right)$}

Untuk melihat dan mengetahui besarnya sumbangan variabel independent terhadap variabel dependen, maka digunakan analisis varian dengan perhitungan determinasi dengan menggunakan model sebagai berikut (Damodar Gujarati, 1999) :

$$
\mathrm{R}^{2}=\mathrm{r}^{2} \mathrm{X} 100 \%
$$

\section{Dimana :}

$$
\mathrm{R}^{2} \quad=\text { Koefisien determinasi }
$$

$\mathrm{r} \quad=$ Nilai koefisien korelasi

Nilai $\mathrm{R}^{2}$ ini menunjukkan seberapa besar variabel independent mampu menjelaskan variabel dependent. Kemudian untuk melihat keeratan hubungan antara variabel independent dengan variabel dependent dilakukan dengan mengambil akar dari $\mathrm{R}^{2}$ sehingga di dapat $\mathrm{R}$ yang semakin rendah mendekati 1 menandakan bahwa hubungan antara variabel independent dengan variabel dependent semakin erat.

\section{HASIL DAN PEMBAHASAN}

\section{Perkembangan PDRB di Provinsi Jambi}

Perkembangan daerah lazimnya ditunjukkan oleh indikator PDRB, walaupun beberapa kelemahan, namun sampai sekarang indikator ini masih tetap bisa diandalkan untuk mengetahui pertumbuhan ekonomi suatu daerah. Pertumbuhan ekonomi merupakan alah satu dasar yang digunakan oleh pemerintah dalam menentukan atau menyusun kebijakan ekonomi karena indikator ini menggambarkan pengukuran hasil-hasil pembangunan secara kuantitas. 
Pertumbuhan ekonomi menunjukkan sejauh mana aktivitas-aktivitas perekonomian akan menghasilkan tambahan bagi masyarakat dalam periode tertentu. Perekonomian dapat dikatakan meningkatnya pertumbuhan bila pendapatan masyarakat lebih besar dari pendapatan pada tahun sebelumnya. Besarnya sumbangan produk domestic bruto juga menentukan besarnya tenaga kerja yang bekerja. Pertumbuhan ekonomi merupakan perbandingan antar produk domestic bruto dan produk domestic bruto pada tahun sebelumnya. Untuk mengetahui gambaran PDRB di Provinsi Jambi dalam kurun waktu 2001-2017 dapat dilihat dari Tabel 1.

Tabel 1. Perkembangan PDRB Provinsi Jambi periode $2001-2017$

\begin{tabular}{ccc}
\hline Tahun & PDRB & \% \\
\hline 2001 & 10.205 .592 & \\
2002 & 10.803 .423 & 5,85 \\
2003 & 11.343 .279 & 4,99 \\
2004 & 11.953 .885 & 5,38 \\
2005 & 12.619 .972 & 5,57 \\
2006 & 13.363 .260 & 5,89 \\
2007 & 14.275 .161 & 6,65 \\
2008 & 15.296 .726 & 6,77 \\
2009 & 16.274 .907 & 6,98 \\
2010 & 17.471 .685 & 7,31 \\
2011 & 18.963 .518 & 8,51 \\
2012 & 20.373 .533 & 7,44 \\
2013 & 21.979 .277 & 6,12 \\
2014 & 23.476 .564 & 5,03 \\
2015 & $25,678.448$ & 6,55 \\
2016 & 27.309 .654 & 5,35 \\
2017 & 28.876 .541 & 5,73 \\
\hline Rata-Rata & & $\mathbf{6 , 2}$ \\
\hline
\end{tabular}

Sumber : Badan Pusat Statistik Provinsi Jambi, 2017(diolah)

Dari Tabel 1 menunjukkan bahwa perkembangan PDRB Provinsi Jambi dari tahun 2001- 2017 mengalami peningkatan setiap tahunnya dengan nilai rata - rata pertumbuhan sebesar 6,2\%. Pertumbuhan yang paling tinggi terjadi di tahun 2011 sebesar 8,51\% hal ini terjadi dikarenakan memadainya infrastruktur yang telah dilakukan pada tahun sebelumnya yang membuat jalannya perekonomian di Provinsi Jambi membaik dari perbaikan jalan maupun informasi. Hal ini membuat lancarnya kegiatan ekonomi. Dan pertumbuhan yang terendah terjadi di tahun 2003 yaitu sebesar 4,9\%. Selama kurun waktu dari tahun 2005 2008 pertumbuhan ekonomi Provinsi Jambi semakin tahun semakin meningkat dari 5,57 \% di tahun 2005 dan ditahun 2007 menjadi 6,65 \% sampai dengan tahun 2008 terus meningkat menjadi 6,77 \%. Dan ditahun - tahun berikutnya pertumbuhan ekonomi berfluktuatif, hingga pada tahun 2016 pertumbuhan ekonomi di Provinsi Jambi mengalami penurunan menjadi sebesar 5,35\%.

\section{Perkembangan industri kecil di Provinsi Jambi}


Dalam meningkatkan industri kecil ini disperindag melakukan pelatihan-pelatihan seperti kegiatan pelatihan bagaimana meningkatkan kualitas barang yang diproduksi, sehingga sumber daya manusia yang ada di Provinsi Jambi agar berinovasi terhadap produk yang dihasilkan. Dengan demikian industri kecil bisa bersaing dengan produk-produk dari luar Provinsi Jambi.

Kebijakan yang dilakukan oleh pemerintah agar industri kecil di Provinsi Jambi terus berkembang adalah menerapkan pengembangan industri berbasis komoditi kompetensi inti daerah.

Untuk menilai posisi strategis kelompok usaha terutama industri kecil hanya akan dapat diperlihatkan melalui kontribusi kelompok usaha menurut sektor ekonomi. Dengam melihat kelompok usaha ini mampu meningkatkan kemampuan potensial kelompok usaha dalam menghasilkan barang dan jasa. Untuk lebih jelas nya dapat dilihat pada Tabel 2 berikut :

Tabel 2. Perkembangan jumlah unit usaha industri kecil di Provinsi Jambi periode 2001 2017

\begin{tabular}{ccc}
\hline Tahun & Unit Usaha & \% \\
\hline 2001 & 55.679 & - \\
2002 & 57.123 & 2,59 \\
2003 & 58.378 & 2,19 \\
2004 & 60.449 & 3,54 \\
2005 & 61.458 & 1,66 \\
2006 & 62.858 & 2,77 \\
2007 & 62.742 & 0,18 \\
2008 & 63.671 & 1,48 \\
2009 & 68.540 & 7,68 \\
2010 & 74.529 & 8,71 \\
2011 & 78.459 & 5,14 \\
2012 & 79.119 & 9,53 \\
2013 & 81.552 & 3,08 \\
2014 & 81.959 & 0,5 \\
2015 & 81.979 & 0,02 \\
2016 & 98.105 & 19,67 \\
2017 & 99.910 & 1,83 \\
\hline Rata-Rata & & $\mathbf{4 , 1 5}$
\end{tabular}

Sumber: BPS Provinsi Jambi, 2017 (diolah)

Berdasarkan Badan Pusat Statistik Perkembangan rata-rata unit usaha industri kecil tahun 2001-2017 adalah sebesar 4.15 persen pertahun, semakin meningkatnya pertumbuhan unit usaha industri kecil selama 16 tahun tidak diimbangi dengan jumlah dalam meningkatkan sumber daya alam yang ada di Provinsi Jambi karena memiliki sumber daya alam.

Tingginya perubahan unit usaha pada tahun 2016 yaitu mencapai $19,67 \%$ hal ini didukung dengan permodalan yang cukup tinggi dan akan berdampak langsung dengan pertumbuhan-pertumbuhan usaha baru, dalam meningkatkan unit usaha baru pada wirausaha perlu peranan pemerintah hal tersebut bertujuan untuk melindungi harga-harga 
pasar yang akan dijual atau distribusikan oleh produsen kepasar dengan harga seimbang sehingga tidak ada ketimpangan antara produsen dengan konsumen dalam melakukan kegiatan ekonomi. (Hapsari, 2014)

Sedangkan pertumbuhan pada tahun 2007 pertumbuhan paling kecil menurun mencapai $0,18 \%$, hal ini disebabkan karena pada tahun tersebut sektor industri kecil di Provinsi Jambi mengalami penurunan yang disebabkan karena tidak mendapat hasil yang memuaskan dalam melakukan kegiatanya yaitu lebih besar dibiayai modal daripada pendapat yang diterima oleh industri kecil. Sehingga pertumbuhan pada tahun tersebut masih sangat rendah yang disebabkan kurangnya modal dan masih sulitnya untuk mendirikan usaha-usaha baru. Dalam memprioritaskan industri kecil dibanding industri besar. (Hapsari, 2014)

\section{Perkembangan tenaga kerja di sektor industri kecil di Provinsi Jambi}

Untuk mencapai pertumbuhan ekonomi yang cukup tinggi, diburuhkan tenaga kerja yang berkualitas dan profuktif. Kondisi ketenagakerjaan di Provinsi Jambi ditandai dengan masih besarnya jumlah tenaga kerja yang terserap di sektor yang produktivitasnya relatif rendah, terutama sektor pertanian tradisonal, dibandingkan dengan tenaga kerja yang terserap disektor non pertanian, khususnya industri dan jasa. Sektor industri dan jasa yang berperan sebagai penggerak percepatan laju pertumbuhan ekonomi daerah memerlukan tenaga kerja dengan produktivitas yang relatif tinggi.(Sukirno,2011)

Tabel 3. Perkembangan tenaga kerja industri kecil di provinsi jambi periode 2001- 2017

\begin{tabular}{ccc}
\hline Tahun & Tenaga Kerja & \% \\
\hline 2001 & 66.376 & 0,97 \\
2002 & 67.024 & 1,03 \\
2003 & 67.721 & 3,33 \\
2004 & 69.980 & 1,77 \\
2005 & 71.224 & 3,12 \\
2006 & 73.451 & 2,64 \\
2007 & 75.392 & 14,45 \\
2008 & 86.286 & 12,63 \\
2009 & 97.181 & 11,21 \\
2010 & 104.042 & 5,83 \\
2011 & 110.108 & 8,92 \\
2012 & 119.932 & 28,2 \\
2013 & 153.761 & 0,25 \\
2014 & 154.147 & 9,17 \\
2015 & 168.288 & 3,06 \\
2016 & 173.442 & 4,8 \\
2017 & 181.843 & $\mathbf{6 , 5}$
\end{tabular}

Sumber : Badan Pusat Statistik Provinsi Jambi, 2017 (diolah)

Dari penjelasan Tabel 3 perkembangan jumlah tenaga kerja sektor industri kecil mengalami fluktuasi yang positif, artinya jumlah tenaga kerja sektor industri kecil mampu terus mengalami penambahan. Pada tabel 3 terlihat bahwa perkembangan penyerapan 
tenaga kerja dari tahun ketahun menunjukkan peningkatan dengan rata-rata 6,65 persen dari tahun 2001-2017. Peningkatan paling tinggi terjadi pada tahun 2013 dengan hasil 28,20\%. Dan terus meningkat ke tahun tahun berikutnya pada tahun 2014 kembali naik sebesar 0,25\%. Kembali naik lagi ke tahun selanjutnya tahun 2015 sebesar 9,17\% dan tahun 2016 sebesar 3,06\%, pada tahun 2017 meningkat menjadi 4,8\%.

\section{Perkembangan investasi sektor industri kecil di Provinsi Jambi}

Investasi mencerminkan sejumlah faktor yang berkaitan dengan lokasi tertentu yang membentuk kesempatan dan insentif bagi pemilik modal untuk melakukan usaha atau investasi yang kondusif. Kegiatan investasi di Provinsi Jambi merupakan pemicu peningkatan pertumbuhan ekonomi, karena itu, investasi perlu di tempatkan sebagai bagian yang penting dari penyelenggaraan perekonomian daerah, yang akan memberikan dampak multiplier efek seperti menciptakan lapangan pekerjaan. Investasi merupakan sebagai pengeluaran dan penambahan penanaman modal atau perusahaan untuk membeli barangbarang modal dan perlengkapan-perlengkapan produksi untuk menambah kemampuan memproduksi barang-barang dan jasa-jasa yang tersedia dalam perekonomian.(Fetroletri, 2015)

Tabel 4. Perkembangan investasi sektor industri di Provinsi Jambi Tahun 2001-2017

\begin{tabular}{ccc}
\hline Tahun & Inv & \% \\
\hline 2001 & 7.593 .298 & \\
2002 & 8.875 .775 & 16,88 \\
2003 & 10.664 .890 & 20,15 \\
2004 & 11.129 .065 & 4,3 \\
2005 & 11.957 .125 & 7,44 \\
2006 & 12.435 .410 & 4,0 \\
2007 & 12.886 .815 & 3,9 \\
2008 & 13.050 .478 & 1,27 \\
2009 & 13.676 .900 & 4,79 \\
2010 & 14.333 .392 & 4,8 \\
2011 & 14.387 .175 & 0,37 \\
2012 & 14.430 .379 & 0,3 \\
2013 & 15.210 .000 & 5,4 \\
2014 & 15.970 .000 & 4,99 \\
2015 & 14.227 .868 & $-10,9$ \\
2016 & 15.717 .941 & 10,47 \\
2017 & 16.753 .329 & 6,58 \\
\hline Rata-Rata & & $\mathbf{4 , 9 8}$ \\
\hline
\end{tabular}

Sumber: BPS Provinsi Jambi Tahun, 2017 (diolah) 
Dalam meningkatkan pertumbuhan industri kecil maka perlunya peranan yang cukup besar dari penambahan modal baik bantuan dari perbankan maupun bantuan dari pemerintah dalam meningkatkan industri kecil yang setiap tahunannya mengalami pertumbuhan yang stabil.atau mengalami peningkatan persentase sebesar 10,47 persen dan 6,58 persen. Dari penjelasan tabel 4 di atas dapat dilihat bahwa perkembangan investasi sektor industry kecil cenderung mengalami fluktuasi dengan tingkat pertumbuhan rata-rata 4,98 persen .

Pada tahun 2001 investasi ditanamkan pada industry kecil sebesar Rp. 7.593 .298 pada tahun 2002 dengan persentase sebesar 16,88 persen dan meningkat menjadi Rp. 8.875.775 . angka ini terus meningkat hingga tahun 2014 yang menjadi sebesar Rp. 15.970.000 dengan persentase sebesar 4,99 persen dari tahun sebelumnya yang mana pada tahun ini merupakan jumlah investasi tertinggi dalam kurun waktu 2001-2014. Akan tetapi pada tahun 2015 mengalami penurunan sebesar Rp. 14.227.868 dengan persentase -10,9 persen. Hal ini terjadi karena pertumbuhan industry kecil di Provinsi Jambi masih sangat rendah maka hal teresebut berdampak pada pertumbuhan ekonomi Provinsi Jambi yaitu hanya 6,2 persen.hal tersebut akan berdampak langsung terjadinya pelambatan investasi. Jumlah investasi yang menurun dikarenakan masih rendahnya perusahaan atau pihak asing yang menanamkan modal dalam upaya untuk peningkatan jumlah perusahaan industri kecil. Namun pada tahun 2016 dan tahun 2017 investasi kembali meningkat menjadi Rp. 15.717.941 dan Rp. 16.753 .329

Pengaruh unit usaha, tenaga kerja dan nilai investasi sektor industri kecil terhadap pertumbuhan ekonomi Provinsi Jambi

Pengujian ini menggunakan regrsi linier berganda untuk mengetahui seberapa besar pengaruh variabel bebas terhadap variabel terikat. Pengujian ini menggunakan aplikasi Eviews 9, berdasarkan pengujian statistic diperoleh model persamaan regresi sebagai berikut. (Gujati,2005). Dari hasil koefisien regresi maka model regresi dapat sederhanakan sebagai berikut

\section{$\mathrm{PE}=6.65172455985+0,00000104857824477 * \mathrm{UU}+0,00000201507584182 * \mathrm{TK}+$ $0,0000000211695918173 *$ INV}

\section{Nilai konstanta $(\alpha)$}

Nilai konstanta sebesar 6.65172455985 hal ini berarti jika unit usaha, tenaga kerja dan nilai investasi sektor industri kecil adalah konstan, maka pertumbuhan ekonomi sebesar $6,6 \%$.

\section{Koefisien unit usaha(X1)}

Koefisien unit usaha sebesar 0,00000104857824477 hal ini berarti setiap peningkatan jumlah satu unit maka akan meningkatkan pertumbuhan ekonomi sebesar 0,0000010\% dengan asumsi variable tenaga kerja, nilai investasi dan pertumbuhan ekonomi relatif tetap atau tidak berubah.

\section{Koefisien tenaga kerja (X2)}


Koefisien tenaga kerja sebesar 0,00000201507584182 hal ini berarti setiap penigkatan satu orang tenaga kerja maka akan meningkatkan pertumbuhan ekonomi sebesar 0,0000020\% dengan asumsi variable nilai investasi, jumlah unit usaha dan pertumbuhan ekonomi keadaan nya relatif tetap atau tidak berubah.

\section{Koefisien nilai investasi}

Koefisien nilai investasi sebesar 0,0000000211695918173 hal ini berarti setiap peningkatan jumlah nilai investasi sebesar Rp. 1.000.000. maka akan meningkatkan pertumbuhan ekonomi sebesar 0,000000021\% dengan asumsi variable tenaga kerja, jumlah unit usaha dan pertumbuhan ekonomi relatif tetap atau tidak berubah.

\section{Tabel 5. Hasil pengujian regresi linier berganda}

\begin{tabular}{crccc}
\hline \hline \multicolumn{1}{c}{ Variable } & Coefficient & Std. Error & t-Statistic & Prob. \\
\hline C & 6.651725 & 0.046562 & 142.8564 & 0.0000 \\
TK & $1.05 \mathrm{E}-06$ & $1.33 \mathrm{E}-06$ & 2.787325 & 0.0452 \\
\multicolumn{1}{c}{ INV } & $2.02 \mathrm{E}-06$ & $3.78 \mathrm{E}-07$ & 5.337061 & 0.0001 \\
& $2.12 \mathrm{E}-08$ & $3.86 \mathrm{E}-09$ & 5.489789 & 0.0001 \\
\hline \hline R-squared & 0.986932 & Mean dependent var & 7.223571 \\
Adjusted R-squared & 0.983916 & S.D. dependent var & 0.146907 \\
S.E. of regression & 0.018631 & Akaike info criterion & -4.925635 \\
Sum squared resid & 0.004513 & Schwarz criterion & -4.729584 \\
Log likelihood & 45.86789 & Hannan-Quinn criter. & -4.906147 \\
F-statistic & 327.2572 & Durbin-Watson stat & 1.772921 \\
Prob(F-statistic) & 0.000000 & & \\
\hline \hline
\end{tabular}

Sumber: Data diolah, 2019

\section{Uji t}

Melihat hasil setiap variabel bebas terhadap variabel terikat secara parsial yang diuji dengan uji-t secara rinci dapat dilihat sebagai berikut ;

\section{Variabel unit usaha industri kecil}

Uji t-statistik untuk variabel unit usaha industri kecil terhadap pertumbuhan ekonomi Provinsi Jambi secara parsial diketahui t-hitung $(2.787325)>t$ tabel $(2,160)$ maka Ho di tolak dan ha di terima. Hal ini berarti bahwa variabel unit usaha berpengaruh signifikan terhadap pertumbuhan ekonomi di Provinsi Jambi .

\section{Variabel tenaga kerja industri kecil}

Uji t-statistik untuk variabel tenaga kerja industri kecil terhadap pertumbuhan ekonomi Provinsi Jambi secara parsial diketahui t-hitung $(5,337)>t$ tabel $(2,160)$ maka Ho di tolak dan ha di terima. Hal ini berarti bahwa variabel tenaga kerja berpengaruh signifikan terhadap pertumbuhan ekonomi di Provinsi jambi .

\section{Variabel investasi industri kecil}

Uji t-statistik untuk variabel investasi industri kecil terhadap pertumbuhan ekonomi Provinsi Jambi secara parsial diketahui t-hitung $(5,4897)>\mathrm{t}$ tabel $(2,160)$ maka Ho di tolak 
dan ha di terima. Hal ini berarti bahwa variabel investasi industri kecil berpengaruh signifikan terhadap pertumbuhan ekonomi di Provinsi jambi .

\section{Uji F}

Uji F digunakan untuk melihat apakah secara simultan variable ( unit usaha, tenaga kerja nilai investasi industri kecil) berpengaruh signifikan terhadap variabel tidak bebas (pertumbuhan ekonomi) di Provinsi Jambi. Dari hasil pengujian diperoleh nilai f hitung sebesar 327.2572 dengan tingkat keyakinan sebesar 95\% $\quad \alpha=5$ df $=\mathrm{N} 1$ (3) $\mathrm{N} 2$ (13) diperoleh $F$ tabel sebesar 3,49 dengan demikian nilai $F$ hitung $(327,2572)>\mathrm{f}$ tabel $(3,41)$ dan dilihat dari probabilita $0,000000<\alpha 0,05$. Artinya secara bersama-sama unit usaha, Tenaga kerja dan nilai investasi industri kecil berpengaruh signifikan terhadap pertumbuhan ekonomi di Provinsi Jambi.

\section{Koefisien determinasi $\left(\mathbf{R}^{2}\right)$}

Koefisien determinasi digunakan untuk mengukur seberapa besar kemampuan variabel independen (Unit usaha Industri kecil, tenaga kerja industri kecil, Investasi industri kecil) dalam menjelaskan variasi dari variabel dependent.

Hasil pengujian diperoleh nilai koefisien determinasi $\left(\mathrm{R}^{2}\right)$ sebesar 0.986932. hal ini menunjukkan bahwa Unit usaha industri kecil, Tenaga kerja industri kecil, Investasi industri kecil mampu mempengaruhi Pertumbuhan Ekonomi sebesar 98,69 persen, sedangkan sisanya 2,31 persen dipengaruhi oleh variabel lain yang tidak termasuk dalam penelitian ini.

\section{KESIMPULAN DAN SARAN}

\section{Kesimpulan}

Pada periode 2001-2017 rata rata perkembangan PDRB Provinsi Jambi selama tahun 2001-2017 adalah 6,2 persen per tahun. Rata-rata perkembangan unit Usaha industri kecil di Provinsi Jambi selama tahun 2001-2017 adalah 4,15 persen pertahun. Rata-rata perkembangan Tenaga kerja indutri kecil di provinsi Jambi selama tahun 2001-2017 adalah sebesar 6,5 persen pertahun. Rata-rata perkembangan Investasi Industri kecil di Provinsi Jambi selama tahun 2001-2017 adalah 4,98 persen pertahun.

Variabel unit usaha industri kecil, tenaga kerja industri kecil dan investasi industri kecil berpengaruh signifikan terhadap pertumbuhan ekonomi di Provinsi Jambi periode 2001-2017 dilihat dari t-statistik > t-hitung dengan pembuktian $(\alpha=5 \%)$

\section{Saran}

Pemerintah selaku pembuat kebijakan diharapkan lebih memperhatikan UMKM yang ada, yaitu dengan melakukan pemberdayaan bagi UMKM seperti pemberian ijin, bantuan modal dan sebagainya. Karena UMKM di Provinsi Jambi memiliki potensi yang baik untuk kemajuan wilayah sehingga dalam jagka panjang dapat membantu meningkatkan pertumbuhan ekonomi.

Pemerintah daerah diharapkan memberi pelatihan dibidang industri kecil bagi masyarakat sehingga menghasilkan tenaga kerja yang memiliki keahlian dibidang industri 
kecil ini sehingga mampu memberikan dampak yang positif terhadap pertumbuhan ekonomi.

Agar perkembangan dan peranan usaha kecil di Provinsi Jambi terhadap laju pertumbuhan sektor usaha kecil, penyerapan tenaga kerja dan perkembangan investasi terus meningkat dan terus memberikan kontribusi yang positif, maka diperlukan adanya perhatian bagi pengusaha dan pemerintah baik dalam permodalan, pembinaan dan pengembangan usaha kecil

\section{DAFTAR PUSTAKA}

A Mulyadi, H Hardiani, E Umiyati. (2018). Faktor-faktor yang mempengaruhi penyerapan tenaga kerja pada sektor industri kecil di Kabupaten Muaro Jambi, e-Jurnal Perdagangan Industri dan Moneter 6 (1), 35-44

Adisasmita, Rahardja.(2013).Teori-teori pembangunan ekonomi, Graha Ilmu : Yogyakarta

Bada Pusat Statistik (BPS).(2017). Industri kecil Provinsi Jambi Tahun 2001-2017. BPS Provinsi Jambi. BPS : Jambi

Badan Pusat Statistik (BPS).(2017). Perkembangan PDRB Provinsi Jambi 2001-2017. BPS Provinsi Jambi. BPS : Jambi

Fetroletri. (2015). Pengaruh industri kecil terhadap pertumbuhan ekonomi kabupaten Kerinci.Skripsi FE Unja. Universitas Negri: Jambi

Gujati, Damordar. (2005). Ekonomitrika dasar. Airlangga : Jakarta

Hapsari, Paramita, Abdul Hakim dan Saleh Soeaid., (2014). Pengaruh pertumbuhan usaha kecil menengah (umkm) terhadap pertumbuhan ekonomi daerah kota batu dalam Jurnal ekonomi dan bisnis. Universitas brawijaya. Di rilis dalam website http://wacana.ub.ac.id/index.php/wacana/article/view/308 pada tanggal 17 februari 2014

J Junaidi, A Amir, H Hardiani. (2014).Potensi klaster agroindustri usaha mikro kecil dan menengah di Provinsi Jambi, Jurnal Perspektif Pembiayaan dan Pembangunan Daerah 2 (1), 9-20

J Junaidi, Z Zulfanetti, H Hardiani. (2014). Analisis kondisi ketenagakerjaan di Provinsi Jambi. Fakultas Ekonomi dan Bisnis Universitas Jambi: Jambi

Junaidi. (2015). Ekonomitrika 1 Dengan program eviews : Universitas Jambi: Jambi

Rahardja, Prathama dan Manurung, Mandala. (2008). Pengantar Ilmu Ekonomi Mikro Ekonomi Dan Makro Ekonomi, Edisi Ketiga, Fakultas Ekonomi Universitas Indonesia: Jakarta

S Sunargo, D Hastuti. (2019).Mengatasi perilaku kerja kontraproduktif melalui peran integratif politik organisasional dan kecerdasan emosional pada era revolusi industri 4.0, Jurnal Paradigma Ekonomika 14 (2), 45-54

Sukirno, Sadono. (2000). Ekonomi Pembangunan. LPE-UI : Jakarta

Todaro, Michel P. dan Stephen C Smith. (2011). Pembangunan Ekonomi Edisi Kesebelas. Erlangga : Jakarta

Widodo, Tri. (2006). Perencanaan Pembangunan. UPP STM YKPN : Yogyakarta 